\title{
Alman Muhasebe Sisteminin Türk Muhasebe Hayatındaki Yeri: Türkiye Cumhuriyeti Devlet Demiryolları Örneği
}

\author{
Bilge Leyli DEMIREL*, Ayşenur TARAKCIOĞLU ALTINAY**
}

ÖZ

Bu çalışmanın amacı 1953-1954 ile 1971-1972 yılları arasında Türkiye Cumhuriyeti kamu işletmelerinde görülen Alman Muhasebe Sistemi etkilerini ortaya koyabilmektir. Bu amaçla çalışmada Türkiye Cumhuriyeti Devlet Demiryolları'nın (TCDD) 1953-1973 yılları arasındaki finansal tabloları incelenmiştir. Bu dönemde Almanya'da kullanılan genel hesap planı ile söz konusu işletmenin hesap planı çeșitli açılardan ve yapısal olarak karşılaștırılarak bir içerik analizi yapılmıştır. Çalışma sonucunda TCDD'de 1953-1971 yılları arasında hazırlanan finansal tabloların yapısının Alman Genel Hesap Planı ile benzer olduğu ve bu benzerliğin 1972 yılından itibaren değiştiği görülecektir. Türkiye Cumhuriyeti bu tarihte hâlen günümüzde de kullandığı Tek Düzen Hesap Planı'na doğru bir geçiş yaşamaya başlamıştır.

Anahtar Kelimeler: Alman Muhasebe Sistemi, Türkiye Muhasebe Tarihi, Türkiye Cumhuriyeti Devlet Demiryolları, Muhasebe Tarihi.

JEL Sinıflandırması: M41, M48, B10

\section{Status of the German Accounting System in Turkish Accounting Life: The Case of The Republic of Turkey State Railways}

\begin{abstract}
The purpose of the study is to reveal the effects of German Accounting System which was seen in public enterprises of the Republic of Turkey between the years 1971-1972 and 1953-1954. For this purpose, the financial statements of State Railways of the Republic of Turkey (TCDD) between 1953-1973 years were analysed in the study. It is made a content analysis by comparing the general account plan used in Germany in this period and the account plan of the mentioned enterprise in various aspects and structurally. As a result of the study, it will be seen that the structure of the financial statements prepared in TCDD between 1953-1971 years was similar to the German General Account Plan and this similarity has changed from 1972. The Republic of Turkey has begun to experience a shift to the Uniform Chart of Accounts, which is also used nowadays, in that date.
\end{abstract}

Keywords: German Accounting System, Turkish Accounting History, State Railways of the Republic of Turkey, Accounting History.

JEL Classification: M41, M48, B10

Geliş Tarihi / Received: 11.03.2019 Kabul Tarihi / Accepted: 20.08.2019

\footnotetext{
* Doç. Dr., Yalova Üniversitesi, İ̈BF, Uluslararası Ticaret ve Finansman Bölümü, bilgeleyli@gmail.com, ORCID: 0000-0002-8807-4631.

** Dr. Öğr. Üyesi, Uşak Üniversitesi, İ̈BF, İşletme Bölümü, aysenur.altinay @ usak.edu.tr, ORCID: 0000-0001-69632346.
} 


\section{GİRIŞ}

1839 yılında ilan edilen Tanzimat Fermanı (Tanzimât-1 Hayriye) ile Osmanlı Devleti bir demokratikleşme sürecine girmiştir. Bu süreç hayatın her alanında kendini hissettirmiştir. Öyle ki bundan Osmanlı Devleti Muhasebe Sistemi de etkilenmiştir. Bu tarihe kadar "Merdiven Kayıt Yöntemi (Stairs Method)" (Elitaş vd., 2008) ile tutulan muhasebe kayıtları "Çift Taraflı Kayıt Tekniğii" olarak bilinen ve günümüzde de "modern kayıt tekniği” olarak kabul edilmiş kayıt yöntemine geçilerek değiştirilmiştir. Çift taraflı kayıt sisteminin ilk olarak 1851 yılında İstanbul'da kurulan Şehir Hatları Vapur İşletmesi (Şirket-i Hayriye)'nde kullanılmaya başlandığı bilinmektedir.

Muhasebe tarihi, milattan önceki dönemlere kadar uzanmaktadır (Sutter, 2007). Diğer bir ifade ile uygarlıkların oluşumu ile muhasebe tarihinin oluştuğunu söylemek mümkündür (Selimoğlu vd., 2009). 19. yüzyıldan itibaren muhasebe sanat veya teknik olma yapısından bilim olma yoluna girdiğinde; İtalya, Fransa ve daha sonra da Almanya'da ortaya çıkan muhasebe okulları, çift yanlı kayıt yöntemini 20. yüzyılın karışık düzenine hazırlamak ile uğraşmışlardır (Güneş vd., 2012).

Bu çalışmanın amacı Osmanlı Devleti'nde çift taraflı kayıt tekniğinin uygulanması ile başlayan muhasebe hayatındaki değişimi Türkiye Cumhuriyeti'nde izleyebilmektir. Bu amaçla Türkiye Cumhuriyeti'nin kuruluşundan (1923) başlayıp 1950-1951'li yıllara kadar devam eden Fransız Muhasebesi etkisi üzerine değil; 1950-1951 gibi başlayıp 1970-1971'li yıllara kadar sürdüğünü düşündüğümüz "Alman Muhasebe" anlayışının (Aysan, 2009: 50 ayrıca bkz. Toraman ve Bayramoğlu, 2006) etkileri incelenmeye ve araştırılmaya çalışılacaktır. Bununla birlikte bu araştırma "Devlet Kurumları Muhasebesi" açısından yapılacaktır. Bu araştırma yapılırken yöntem olarak içerik analizi tekniği kullanılacaktır. Söz konusu yıllarda Türkiye Cumhuriyeti Devlet Muhasebesinin kullanıldığı işletmelerden biri olan Türkiye Cumhuriyeti Devlet Demiryollarının (TCDD) finansal tablolarının (bilanço - gelir tablosu) yapısı "Genel Alman Finansal Tablo Yapısı" ile çeşitli açılardan karşılaştırılacaktır. Bu karşılaştırma "hesap planları" üzerinde yapılacak olup temel değerlendirme başlıkları;

(a) dış yapı bakımından [harflerle simgeleme, rakamlarla simgeleme ve karma simgeleme yöntemlerinden hangisi seçilmiştir],

(b) iç yapı bakımından [hesaplara düşlen işlem yoğunluğu ilkesi, bilançoya göre bölümleme ilkesi, işletmede geçen eylemlere göre bölümleme ilkesi ve iktisadi değer dolaşımı ilkesi açısından durumu nedir sorularına yanıt aranacaktır],

(c) muhasebe kayıt yöntemi açısından [tek taraflı kayıt yöntemi, çift taraflı kayıt yöntemi veya karma kayıt yönteminden hangisi tercih edilmiştir] ve

(d) muhasebe sistemi açısından [aşırı birci (monist), aşırı ikici (dualist), ölçülü birci (limited monist) ve ölçülü ikici (limited dualist) muhasebe sisteminden hangisi tercih edilmiş] olacaktır.

Çalışma bu amaçla Türk muhasebe tarihi sürecinin özet olarak verilmeye çalışılacağ birinci bölümün ardından, Alman muhasebe sisteminin yine temel unsurları ile tanıtılacağı ikinci bölüm ile devam edecektir. Üçüncü bölümde ise TCDD'nin 1953-1975 yılları arasındaki finansal tablolarının incelenmesi ile devam edecektir. Bu bölümde 1972 yılından itibaren değişen finansal tablo yapısı ile Alman muhasebe sistemi etkisinin terk edildiği de gösterilmeye çalışlacaktır. Bu tarihten itibaren başlayan ve günümüzde de hâlen Türkiye'de işletmelerce kullanılan finansal tablo yapısına geçilmiş olacağı görülecektir. Çalışmanın dördüncü ve son bölümünde ise elde edilen veriler ve yapılan tespitler bağlamında genel değerlendirmeler ile sezgisel kanaatlere yer verilecektir. 


\section{LITERATÜR TARAMASI}

Osmanlı Devleti'nin son dönemleri ile Cumhuriyet ve Cumhuriyet sonrası dönemlerde Türk muhasebe literatüründe muhasebecilerin ve muhasebe derslerinin Fransiz ve Alman ekollerinden etkilendiğini görmek mümkündür. Alman ve Fransız muhasebe uygulamaları o dönem itibariyle az sayıdaki Türk muhasebe eğiticilerini ve çok az sayıdaki özel sektör muhasebe uygulamalarını ve İktisadi Devlet Teşekküllerindeki (IDT) muhasebe uygulamalarını doğrudan etkilemiştir (Aysan, 2009). Türkiye'de muhasebe uygulamaları ve eğitimi Cumhuriyet öncesinde başlamış ve 1926'da ve daha sonrasında da Fransız ekolü etkisinde ilerlemiştir (Aysan, 1995). Fransız etkisini takiben Türkiye muhasebe eğitiminde bir Alman etkisinin başladığ 1 söylenebilir. $\mathrm{Bu}$ dönemde üniversitelerde muhasebe eğitiminin verildiği kürsüler kurulmuş ve muhasebe eğitimi yaygınlaştırılmıştır (Bayazıtlı, 2000, 40) Örten (1988) çalışmasında 1960 sonrasında Türkiye muhasebe eğitiminde Amerikan ve İngiliz (AngloSakson) etkisinin arttığını kaydetmektedir (Örten, 1988). Ancak özellikle İktisadi Devlet Teşekküllerinde (IDT) Alman bilanço yapısının 1972 yılına kadar görülebildiğini söylemek mümkündür.

Türk muhasebe literatürünün ve mevzuatının gelişiminde yoğun ekonomik ve siyasi ilişkilerimizin olduğu ülkelerden etkilenilmiştir. Muhasebe uygulamalarımızda öncelikle Fransa ve ardından da Almanya'nın önemli etkileri olmuştur (Toraman ve Bayramoğlu, 2006).

Cumhuriyet döneminde 1926 yılında yürürlüğe giren 856 sayılı Ticaret Kanunu'nun Alman Ticaret Kanunu'na dayanması nedeniyle bir süre Alman muhasebe literatürünün etkisi gözlenmiştir. Bu nedenle Alman etkisinin bu yıllarda başlayıp 1960'lara kadar sürdüğü yönünde tespitler de mevcuttur (Akdoğan ve Aydın, 1987).

1950 yılında yürürlüğe giren Gelir Vergisi ve Vergi Usul Kanunlarının, 1956 yılında yürürlüğe giren 6752 sayılı Ticaret Kanunu'nun, muhasebe konusunda önemli gelişmelerin gerçekleşmesini sağladığ 1 görülmektedir. 01.01.1972 tarihinden itibaren Kamu İktisadi Teşebbüslerinde Tekdüzen Muhasebe Sistemi (07.07.1971 gün ve 7/2767 say1lı Kararname ile) uygulamaya konulmuştur (Sevilengül, 2000). Böylece Türkiye'de ilk defa bir tekdüzen hesap planı mantığına sahip bir hesap planı kullanılmaya başlanmıştır.

Türkiye'de muhasebe kurallarının hukuk normu halinde önce Fransız, daha sonra da Alman etkisinde geliştiği ve Kara Avrupası geleneğine dâhil olduğu belirtilmelidir. Daha önceden de belirtildiği üzere 1957 yayımlanma tarihli Türk Ticaret Kanunu ve 1961 yayımlanma tarihli Vergi Usul Kanunu uzunca bir zaman muhasebe uygulamalarını şekillendirmiştir (Arıkan, 1996). Bu yasal düzenlemelerin Alman etkisi ile oluşturulduğu da unutulmamalıdır. Bu nedenle kanunlarla şekillenen muhasebe, kanunların kaynağı olan Alman ekolüne yatkınlığı da beraberinde getirmiştir.

1926 yılında yürürlüğe giren 865 Sayılı Türk Ticaret Kanunu, Alman Ticaret Kanunu'ndan çeviri yolu ile alınmış olması nedeniyle bu tarihten sonra muhasebe yazınında Alman etkisinin başladığı söylenebilir (Bilginoğlu, 1988).

Çürük (2001) gelişmekte olan ülkelerden biri olan Türkiye'nin muhasebe eğitiminin herhangi bir ülkeden doğrudan alınmamakla birlikte birçok gelişmiş ülkeden etkilendiğini belirterek bunları sırasıyla Fransa, Almanya ve Amerika Birleşik Devletleri olarak ifade etmektedir.

1926 - 1960 döneminde, daha önce Fransız ekolünden etkilenen Türk muhasebe yazınının, bu tarihler arasında Almanya'dan kaçarak Türkiye'ye gelen muhasebe öğretim elemanlarının katkılarıyla Alman etkisi altına girdiği dönem olarak kabul edilmektedir (Ünal ve Doğanay, 2009). 


\section{TÜRKIYYE COĞRAFYASINDA MUHASEBE GELISSMELERİ}

Bu başlık altında Osmanlı Devleti'nden Türkiye Cumhuriyeti'ne uzanan süreçte 1850 yılından günümüze kadar bu coğrafyada yaşanan önemli muhasebe gelişmeleri ele alınacaktır. Söz konusu gelişmeler kronolojik bir sıra ile verilecektir. Böylece gelişimin daha açık bir şekilde görülebileceği umulmaktadır. Kronolojik sıralama, TÜRMOB'a ait kurumsal internet sayfasından edinilen bilgiler kullanılarak yazarlar tarafından uyarlanarak geliştirilmiştir.

1. İlk Türk Ticaret Kanunu (Fransız Ticaret Kanunu'ndan uyarlanmıştır - 1850)

2. İstanbul Ticaret Odası'nın (İTO) Kuruluşu (1881)

3. İstanbul Ticaret Lisesi'nin Kuruluşu (1882)

4. Serbest Muhasebeci Mali Müşavirlerin Vergi Denetimi İçin Yetkilendirilmesi (1926-1934)

5. Çok Ortaklı Kamu İşletmelerinin Kuruluşu (1922-1938)

6. İkinci Türk Ticaret Kanunu (Alman Ticaret Kanunu’ndan uyarlanmıştır - 1926)

7. İlk Taslak Muhasebe Meslek Kanunu'nun Hazırlanması (1932)

8. Alman Uzmanlarca Kamuya Ait İşletmeler İçin Muhasebe Sistemlerinin Geliştirilmesi (1937)

9. İlk Kez Yabancı Sermaye Şirketi Denetimine Başlanması (1939)

10. Türkiye Muhasebe Uzmanları Derneği’nin (TMUD) Kuruluşu (1942)

11. Türk Vergi Sistemi’nde Değişiklik Yapılması (1949)

12. Yabancı Sermaye Teşvik Kanunu'nun Kabulü (1950)

13. Üçüncü Türk Ticaret Kanunu (1957)

14. ABD'li ve Türk Akademisyenlerce Hazırlanan Kamuya Ait İşletmeler İçin Muhasebe Sistemlerinin Geliştirilmesi Raporunun Yayınlanması (1968-1970)

15. Kamu İşletmeleri İçin Tekdüzen Muhasebe Sistemi, Genel Kabul Görmüş Muhasebe İlkeleri ve Yönetim Raporlama Sistemlerinin Oluşturulması (1968-1970)

16. Türkiye'de İlk Denetim Şirketinin Kurulması, Uluslararası Denetim Firması Touch Ross ve Türk Ortakları (1967)

17. İlk Yerel Denetim Şirketinin Kurulması ve Türkiye Muhasebe Uzmanları Derneği (TMUD) Üyelerince ABD Dış Ticaret Bankası'nın Denetimi (1971)

18. Türkiye Muhasebe Uzmanları Derneği (TMUD) üyelerini lisans mezunu olup da 2 yıllık mesleki eğitim aldıklarından sonra yapılan sınavı geçmeleri halinde belge düzenleyerek almaya başladı (1974)

19. Mali Müşavirler ve Muhasebeciler Birliği Derneği kurulmuştur (1976)

20. Uluslararası Muhasebeciler Federasyonu'nun Kuruluşu (IFAC), Türkiye Muhasebe Uzmanları Derneği'nin (TMUD) kurucu üye olarak katılımı ve aynı sene Uluslararası Muhasebe Standartları Kurulu'na Üyeliğinin Kabulü (1977)

21. Sermaye Piyasaları Kanunu'nun Kabulü ve Borsa Faaliyetleri Düzenlemeleri (1983)

22. Serbest Muhasebeci Mali Müşavirlerin Vergi Usul Kanunu'na Dâhil Edilmesi (1985)

23. Serbest Muhasebeci Mali Müşavirlerin Vergi Usul Kanunu'na Dâhil Edilmesinin İptali (1987) 
24. Sermaye Piyasalarında Faaliyet Gösteren Bankalar ve İşletmeler İçin Bağımsız Harici Denetim İşlemlerinin Başlatılması, Denetim Firmalarının Kaydı (1987)

25. Bağımsız Denetim Derneği’nin Kuruluşu (1988)

26. 3568 Sayılı Serbest Muhasebeci Mali Müşavirlik ve Yeminli Mali Müşavirlik Kanunu'nun Yayımlanması ile Muhasebe ve Denetim Mesleğinin Tanınması (1989)

27. Uluslararası Muhasebe Standartları'nın Türkiye Muhasebe Uzmanları Derneği (TMUD) Tarafından Türkçeye Çevrilmesi ve Yayımlanması (1991)

28. Tekdüzen Muhasebe Sisteminin Yayımlanması ve Finansal Tabloların Vergi İdaresince Vergi Muhasebesine Dayalı Olarak Tanınmasını İçeren Reformlar (1992)

29. Tüm Muhasebe Meslek Mensuplarınca Gerçekleştirilen, Sınırlı Biçimde Ön Denetim Olarak Yapılan, Vergi Beyanlarının Temelini Oluşturan Ekonomik İlkeleri Kullanarak Ele Alınan Bilanço Uygunluk Denetimi Uygulamalarının Hukuken Kabulü (1994)

30. Bankalardan Kredi Talep Eden İşletmeler İçin Vade Süresi İçinde veya Başvuru Öncesinde Denetim Yapılması İhtiyacının Kabulü (1994)

31. Türkiye Serbest Muhasebeci Mali Müşavirler ve Yeminli Mali Müşavirler Odaları Birliği’ne (TÜRMOB) bağlı Temel Eğitim ve Staj Merkezi'nin (TESMER) Kuruluşu (1992)

32. Muhasebe Standartlarının Geliştirilmesi İçin TÜRMOB Tarafından Türkiye Muhasebe ve Denetim Standartları Kurulu'nun (TMUDESK) Kurulması (1993)

33. Denetimle İlgili Çalışma Kurallarının Kabulü (1994)

34. Anonim Şirketlerde Ortakların Özkaynaklarının Saptanması İçin Ticaret Kanunu'nun TÜRMOB Üyelerine Denetim Yetkisi Vermesi (1995)

35. Kooperatif İşletmelerinde Denetim İhtiyacının 1000’den Fazla Ortağa TÜRMOB Üyeleri İle Tanitımı (1995)

36. Denetimin Çerçevesini ve Denetim Öncesi Teknikleri Düzenleyen Sınırlı Denetim Çalışma Kurallarının Kabulü (1996)

37. Uluslararası Muhasebeciler Federasyonu'nun (IFAC) Muhasebe Mesleği Etik Kurallarıyla Uyumlu Bulunan Muhasebede Etik Çalışma Kurallarının Kabulü (1996)

38. Uluslararas1 Muhasebeciler Federasyonu'nun (IFAC) Eğitim Kurulunca Yayımlanan "Sürekli Mesleki Eğitim Yönergeleri” ile Uyumlu Sürekli Mesleki Eğitim Çalışma Kurallarının Kabulü (1999)

39. Türkiye Muhasebe Standartları Kurulu'nun (TMSK) Kuruluşu ve Görevlendirilmesi (2002)

40. Bağımsız ve Özerk Bir Türkiye Denetim Standartları Kurulu'nun (TÜDESK) TÜRMOB Bünyesinde Kuruluşu ve Görevlendirilmesi (2003)

41. Uzaktan Eğitim Sistemi’nin TESMER Tarafından Tanıtımı (2003)

42. Uluslararası Denetim ve Sigorta Standartları'nın TÜDESK Tarafindan Türkçeye Çevrilmesi ve TÜRMOB Tarafından Yayımlanması (2004)

43. Türkiye Muhasebe Standartları Kurulu'nca (TMSK) Tarafından Hazırlanan, IFRS ile Benzeşen, Türkiye Muhasebe Standartları'nın 2006'da Geçerli Olacak İlk Seti (2005)

44. 3568 Sayılı Serbest Muhasebeci Mali Müşavirlik ve Yeminli Mali Müşavirlik Kanunu'nda Değişiklik Yapılması (2009) 
45. TMSK Tarafindan Hazırlanan, IAS/IFRS ile Tamamen Benzeşen, Türkiye Muhasebe Standartları (TMS) / Türkiye Finansal Raporlama Standartları (TFRS) Tüm Set (2010)

46. 2013'te Geçerli Olacak KOBİ'ler İçin TFRS (2010)

47. Türkiye Muhasebe Standartları'na Uyum Amaçlı Düzenlenen, Denetime Tabi, Kamu Gözetimi Muhasebe ve Denetim Standartları Kurumu'na Yetki Sağlayan, Tüm İşletmeler İçin TMS/TFRS Kullanımını Gerektiren Yeni Türk Ticaret Kanunu (2011)

48. Türkiye Muhasebe Standartları ve Türkiye Finansal Raporlama Standartları'nın tekrardan çevirisi ile güncellenmesi (2012 halen de devam etmektedir)

49. Türkiye'de bağımsız denetime tabi olup Tam Set TMS/TFRS uygulamak zorunda olmayan işletmeler için Yerel Finansal Raporlama Çerçevesi (YFRÇ) (2016)

50. Türkiye'de bağımsız denetime tabi olup Tam Set TMS/TFRS uygulamak zorunda olmayan işletmeler için geçerli finansal raporlama çerçevesi BOBİ FRS adı ile 29 Temmuz 2017 tarihinde yayımlanmıştır (2017)

Kronolojik sıralamadan da görüleceği üzere 1850-2011 yılları arasında önemli dönüm noktası olarak kabul edilebilecek pek çok düzenleme, durum ve gelişme yaşanmıştır. Ortalama her üç buçuk yılda bir bu coğrafyada muhasebeye yön veren önemli bir değişiklik meydana gelmiştir.

\section{GENEL OLARAK ALMAN MUHASEBE SISTEMININ ÖZELLİKLERİ}

Almanya için tek ve genel bir hesap planı olmadığı 1 ve sektörlere göre hesap planlarında bazı değişiklikler olabileceği söylenebilir.

İlk olarak 1897'de tanıtılan Alman Ticaret Kanunu (HGB), teknik olarak temel muhasebe düzenlemesinin kaynağını oluşturur. Bununla birlikte, bu yasada, AB düzenlemeleri HGB'yi değiştirerek Alman hukukuna uyarlanıncaya kadar finansal raporlamaya ilişkin çok ayrıntılı kurallara yer verilmemiştir (Zimmermann vd., 2008).

Almanya'da 1937 yılında Bakanlar Kurulu Kararı ile bir "Zorunlu Hesap Çerçevesi” benimsenmiştir. Bu hesap çerçevesinin Eugen Schmalenbach'ın 1927 yılında hazırladığı hesap çerçevesinden yararlanılarak oluşturulduğu söylenebilir (Yazıc1, 1998). Almanya'da 11 Aralık 1937 tarihinde "Göring Emirnamesi" ile muhasebede bir genel muhasebe planı uygulanması zorunlu hale getirilmiştir (Koç, 1972). Bu hesap çerçevesinin 2. Dünya Savaş1 sonuna kadar kullanıldığ1 söylenebilir. Ancak bundan sonra Alman Endüstri Birliği (Bundesverband der Deutschen Industrie - BID) yeni esasları olan bir hesap planı üzerinde çalışmıştır ve 1953 yılında bir tek düzen hesap planı belirlenmiştir. Bu yeni hesap planında 1. basamaktaki sayılar (0'dan 9'a kadar) hesap sınıflarını temsil etmekte olup, toplam 10 hesap sınıfı belirlenmiştir (Kroll, 2000). Aşağıda Alman Ticaret Kanunu (HGB)'na göre belirlenmiş olan hesap sınıfları yer almaktadır. Buna göre söz konusu hesap sınıfları şöyledir ${ }^{1}$;

$$
\text { Bilanço Aktif Tarafı }
$$

A Duran Varlıklar

B Dönen Varlıklar

C Tahakkuklar ve Ertelenmiş Gelirler

\footnotetext{
1 Alman Ticaret Kanunun (Deutsche Handelsgesetzbuch), Yayınlanma Tarihi: 10.05.1897, Güncellenme Tarihi: 20/12/2012, s. 50-51.
} 
D Ertelenmiş Vergi Varlıkları

E Varlık Tahsisi Aktif Fark1

Bilanço Pasif Tarafı

A Özkaynaklar

B Karşılıklar

C Borçlar (Yükümlülükler)

D Tahakkuklar ve Ertelenmiş Gelirler

E Ertelenmiş Vergi Yükümlülükleri

Gelir Tablosu (Gelir-Gider / Kâr-Zarar Tablosu) Hesaplar1²

$1 \quad$ Gelirler

2 Diğer Gelirler

3 Mamul/Hizmet/Mal Maliyeti

4 Personel Giderleri

5 Amortisman ve İtfa Payları

6 Diğer Giderler

$7 \quad$ Vergi

$8 \quad$ Net Gelir

Almanya kayıt sistematiği olarak ise "Alman Usulü Defter Tutma Yöntemi”"ni tercih etmiştir. Aşağıda yer alan Şekil 1'de bu yönteme göre kayıt süreci görülebilmektedir.

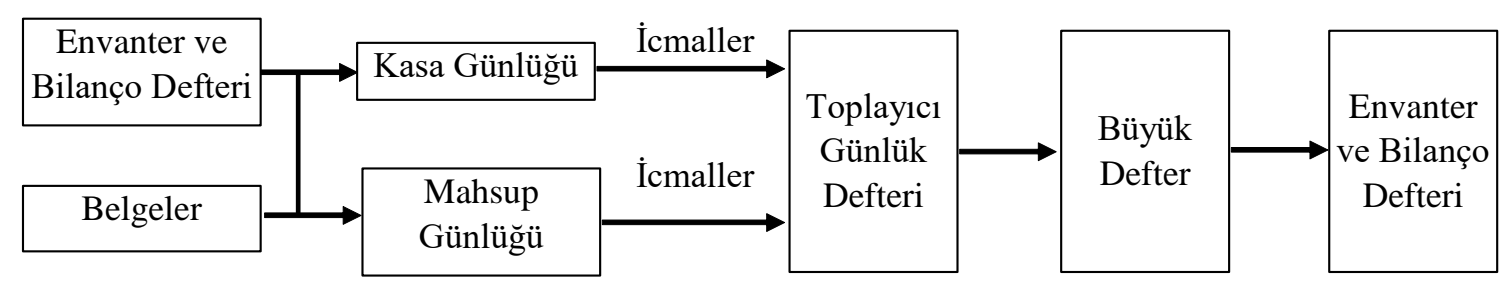

Şekil 1: Alman Usulü Defter Tutma Yöntemi

Kaynak: (Elitaş, 2014).

Şekil 1'den de görüleceği üzere Alman usulü defter tutmada, dönem başındaki varlık ve sermaye tutarı, envanter ve bilanço defterinden ve işletme olayları tutarları, belgelerden tarih sırasına göre, nakit ile ilgili olanlar kasa günlük defterine nakit ile ilgili olmayanlarda genellikle ay sonlarında icmallerle toplayıcı günlük deftere (Genel Günlük Defterine) aktarılır. Bu defter,

2 Alman Ticaret Kanunun (Deutsche Handelsgesetzbuch), Yayınlanma Tarihi: 10.05.1897, Güncellenme Tarihi: 20/12/2012, s. 56. 
günlük defterle büyük defter arasında yer alır. Görevi; aynı türden tutarları bir araya getirmektir. Buradan dönem sonlarında tutarlar ve artakalanlar tespit edilir. Yeniden envanter ve bilanço defterine işlenir. $\mathrm{Bu}$ şekilde hesapların dolaşımı yenilenmiş olur. Organizasyon gerektiğinde iki günlük defter yerine dört günlük defter de tutabilir (Elitaş, 2014).

Çalışmanın bu kısmında Fransız genel hesap planından da bahsetmek gerekmektedir. Çünkü tek düzen muhasebe sistemi konusu ilk olarak 15-16 Aralık 1880 tarihinde yapılan Fransız Muhasebeciler Kongresi'nde tartışılıp ele alınmasına rağmen, sistemi genel ekonomik seviyede uygulama başarısı Almanya'ya aittir (Koç, 1972). Bu iki ülkenin tek düzen hesap planlarının birbirine yakın olduğu düşünüldüğünden aradaki farkın açıç̧a ortaya konmasının çalışmamız açısından önemli olduğunu düşünmekteyiz.

Fransız Genel Muhasebe Planı (1947) (Yazıc1, 1998);

1 Sürekli Sermaye

2 Sabit Değerler

3 Stoklar

4 Üçüncü Kişi Hesapları

$5 \quad$ Finansal Hesaplar

6 Masraf Türleri

$7 \quad$ Hasılat Türleri

8 Sonuç Hesapları

9 İşletme Muhasebesi Hesapları

$0 \quad$ İstatistik Hesaplar1

şeklindedir.

Fransa kayıt sistematiği olarak ise "Fransız Usulü Defter Tutma Yöntemi"'ni tercih etmektedir. Bu yöntemde; dönem başındaki varlık ve sermaye tutarları, envanter ve bilanço defterinden ve işletme olayları belgelerden tarih sırasına göre çeşitli özel günlük defterlere işlenir. Bunlar; kasa, bankalar, alacak senetleri, borç senetleri, alışlar, satışlar ve çeşitli günlük defter diye anılırlar. Bu özel günlük defterlerin sayısı işletmenin büyüklüğüne ve yapılan iş bölümüne göre değişir. Bütün bu özel günlük defterlere yapılan işlemler icmaller (toplamlar) yoluyla toplayıcı günlük deftere ve oradan da büyük deftere aktarılır. Hesap dönemi sonunda büyük defterlerdeki hesapların artakalanlarından yine envanter ve bilanço defterine geçirilir ve burada dolaşım yeniden başlar (Elitaş, 2014). Bu anlatılanları aşağıda yer alan Şekil 2'de görmek mümkündür.

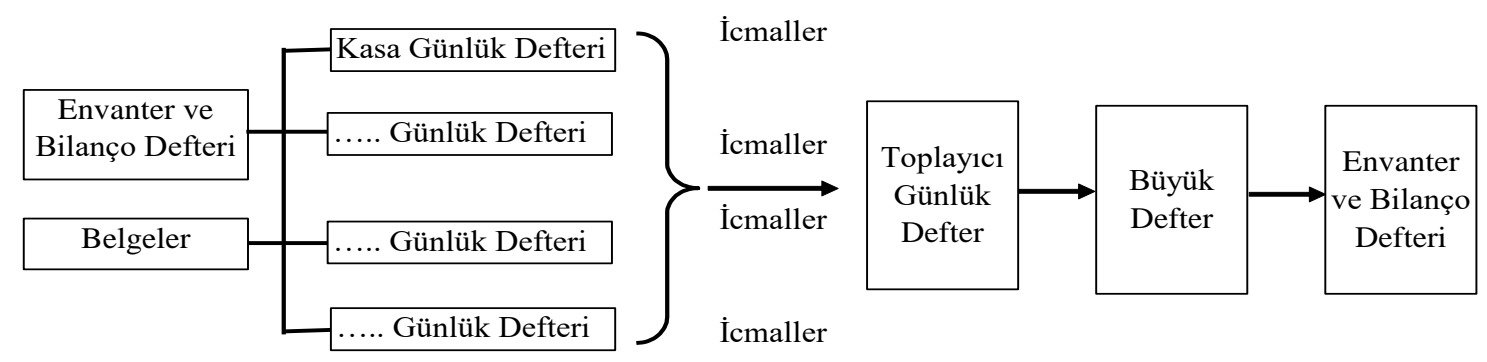

Şekil 2: Fransız Usulü Defter Tutma Yöntemi

Kaynak: (Elitaş, 2014). 
Alman ve Fransız kayıt sistematikleri genel anlamda birbirine önemli derecede yakın olsa da özellikle finansal tablolardaki sınıflama farklılı̆̆ 1 iki sistemin birbirinden ayrılmasında önemli bir ipucu görevi görecektir. Almanya ve Türkiye'deki kayıt sistematiğinin yakın olmasından dolayı Türkiye'de hangi dönem hangi ülkenin etkisinin olduğunu sağlıklı bir şekilde ortaya koyabilmek amacıyla finansal tabloların incelenmesi büyük önem taşımaktadır ve bu yol ile bir genelleme ve ayrıştırma yapılabilecektir.

\section{GENEL OLARAK TÜRK MUHASEBE SISTEMININ ÖZELLIKLERİ}

26/12/1992 tarihinde yürürlüğe giren ancak 01/01/1994 tarihinden itibaren uygulanmakta olan Tek Düzen Hesap Planı "likidite" esasına dayanmaktadır. Bu hesap planından da önce Türkiye'de bazı hesap planı uygulamaları gündeme gelmiştir.

Örneğin; 1968 yılında İktisadi Devlet Teşekküllerini Yeniden Düzenleme Komisyonu (IDTYDK)'nun tek düzen hesap planı temel yapı olarak şöyledir (Yazıcı, 1998);

$\begin{array}{ll}100-190 & \text { Dönen Varlıklar } \\ 200-299 & \text { Duran Varlıklar } \\ 300-399 & \text { Kısa Vadeli Borçlar } \\ 400-479 & \text { Uzun Vadeli Borçlar } \\ 480-499 & \text { Özkaynaklar } \\ 500-599 & \text { Hasılat Hesapları } \\ 600-699 & \text { Maliyet, Giderler ve Zararlar } \\ 700-799 & \text { Fonksiyonel Maliyet ve Gider Hesapları } \\ 800-899 & \text { Kâr ve zarar İcmal ve Dağıtım Hesapları } \\ 900-999 & \text { Serbest } \\ 000-099 & \text { Serbest }\end{array}$

Ayrıca 1984-1989 y1lları arasında kullanımda bulunan Sermaye Piyasası Kurulu Standart Genel Hesap Planı da örnek olarak gösterilebilir. Bu hesap planı ise (Yazıc1, 1998);

$\begin{array}{lll}\text { I } & 100-199 & \text { Dönen Varlıklar } \\ \text { II } & 200-299 & \text { Duran Varlıklar } \\ \text { III } & 300-399 & \text { Kısa Vadeli Borçlar } \\ \text { IV } & 400-479 & \text { Uzun Vadeli Borçlar } \\ \text { V } & 480-499 & \text { Öz Sermaye } \\ \text { VI/A } & 500-599 & \text { Çeşitlerine Göre Giderler } \\ \text { VI/B } & (0-9) & \text { Çeşitlerine Göre Giderler } \\ \text { VII/A } & 600-699 & \text { Gider Yerleri } \\ \text { VII/B } & 10-99 \text { Gider Yerleri } \\ \text { VIII } & 700-799 & \text { Sonuç Hesapları } \\ \text { IX } & 800-899 & \text { Fonksiyonlarına Göre Giderler Yansıtma ve Fark Hesapları } \\ \text { X } & 900-999 & \text { Nazım (İstatistik) Hesapları }\end{array}$


şeklindedir.

Ancak Türkiye'de 01/01/1994 tarihinden itibaren kullanılan Tek Düzen Hesap Planı ise içerik olarak şöyledir:

1 Dönen Varlıklar

2 Duran Varlıklar

3 Kisa Vadeli Yabancı Kaynaklar

4 Uzun Vadeli Yabancı Kaynaklar

5 Özkaynaklar

6 Gelir Tablosu Hesapları

7 Maliyet Hesapları

8 Serbest

9 Nazım Hesaplar

$0 \quad$ Serbest

Türkiye kayıt sistematiği olarak ise "İtalyan Usulü Defter Tutma Yöntemi"”ni tercih etmiştir. Aşağıda yer alan Şekil 3'de bu yönteme göre kayıt süreci görülebilmektedir.

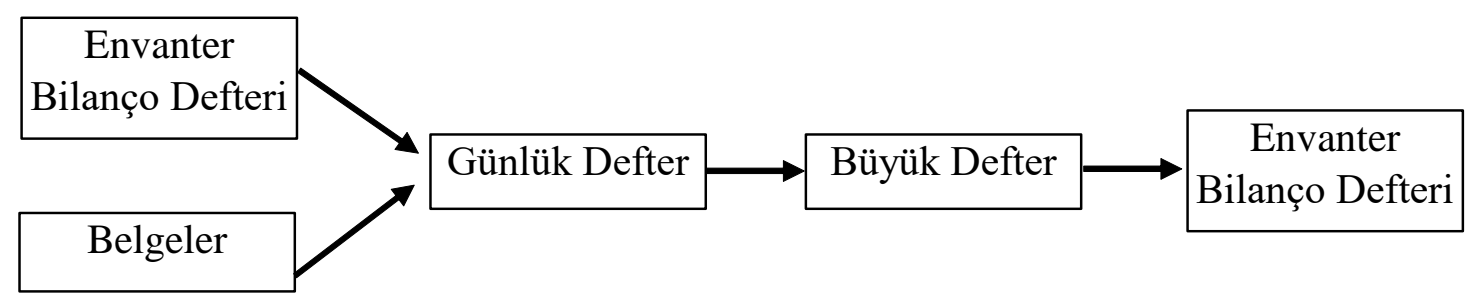

Şekil 3: İtalyan Usulü Defter Tutma Yöntemi

Kaynak: (Elitaş, 2014).

İtalyan usulü defter tutmada; varlık, borç ve sermaye tutarı, envanter ve bilanço defterinden ya da açılış envanter listelerinden ve açılış bilançosundan; işletme olguları ise belgelerden tarih sırasına göre yevmiye (günlük) deftere işlenir. Bu defterden aynı tür tutarlar büyük defterdeki aynı hesaplara ve gereksinmeye göre bölümlenmiş yardımcı defterlerdeki aynı hesaplardaki hesapların artakalanları yeniden envanter ve bilanço defterine işlenir. $\mathrm{Bu}$, kapanış envanteri ve kapanış bilançosudur. Kapanan hesap döneminin envanter ve bilançosu, bu dönemi izleyen hesap döneminin aç1lış envanteri ve aç1lış bilançosu olarak işlem görür (Elitaş, 2014). 


\section{KISACA TÜRKIYYE CUMHURIYETI DEVLET DEMIRYOLLARI'NIN TARİH ${ }^{3}$}

Osmanlı coğrafyasında demiryolunun tarihi, 1851 yılında 211 km'lik Kahire-İskenderiye Demiryolu hattının imtiyazının verilmesiyle başlamıştır. Bugünkü milli sınırlar içindeki demiryollarının tarihinin başlangıcı ise 23 Eylül 1856 yılında 130 km’lik İzmir-Aydın Demiryolu hattının imtiyazının verilmesi ile olmuştur.

Osmanlı Demiryolları, bir süre Bayındırlık Bakanlığı (Nafia Nezareti)'nın Yol ve İnşaat (Turuk ve Meabir) Dairesi tarafından yönetilmiştir. 24 Eylül 1872 tarihinde de demiryolu yapım ve işletmesini gerçekleştirmek üzere "Demiryolları İdaresi” kurulmuştur.

Cumhuriyetin kurulması ve demiryollarının devletleştirilmesine karar verilmesinden sonra Demiryolu işletmeciliği için 24 Mayıs 1924 tarih ve 506 sayılı Kanun ile Bayındırlık Bakanlığına (Nafia Vekâletine) bağlı "Anadolu- Bağdat Demiryolları Müdüriyeti Umumiyesi" kurulmuştur.

"Devlet Demiryolları ve Limanları İşletme Umum Müdürlüğü” adıyla 1939 yılında Ulaştırma Bakanlığı (Münakalat Vekaleti)'na bağlanmıştır. Cumhuriyet öncesinde yapılan ve yabancı şirketler tarafından işletilen hatlar, 1928-1948 yılları arasında satın alınarak millileştirilmiştir.

22 Temmuz 1953 tarihine kadar katma bütçeli bir devlet idaresi şeklinde yönetilen kuruluş, bu tarihte çıkarılan 6186 sayılı Kanunla Ulaştırma Bakanlığına bağlı olarak "Türkiye Cumhuriyeti Devlet Demiryolları İşletmesi (TCDD)" adı altında İktisadi Devlet Teşekkülü haline getirilmiştir.

Son olarak, 08.06.1984 tarih ve 233 sayılı KHK ile de "Kamu İktisadi Kuruluşu" hüviyetini alan ve TÜLOMSAŞ, TÜDEMSAŞ ve TÜVASAŞ olmak üzere üç adet bağlı ortaklığı bulunan TCDD; halen Ulaştırma, Denizcilik ve Haberleşme Bakanlığının ilgili kuruluşu olarak faaliyetini sürdürmektedir.

\section{TÜRK VE ALMAN FINANSAL TABLO YAPISININ ANALIZİ}

Daha önceden de belirtildiği üzere günümüzde Türkiye'de kullanılan Tek Düzen Hesap Planı'nın yapısı likidite esaslı iken, Türkiye'de 1935-1971 yılları arasında farklı bir tek düzen hesap planı yapısının kullanıldığg görülmektedir. Bu zaman aralığında kullanılan yapıda bilanço likit varlıklar yerine durağan varlıklar ile başlamaktaydı. Bu yapının Fransız Genel Muhasebe Planı'ndan farklı olduğunu düşünmekteyiz çünkü bu hesap planı "duran kaynaklar" ile başlamaktadır. Bu durumda inceleme örneği olarak seçtiğimiz Türkiye Cumhuriyeti Devlet Demiryolları (TCDD) finansal tablolarının "Alman Hesap Çerçevesi" ile uyumlu olduğu yönündeki kanaatimizi arttırmaktadır. Aşağıda yer alan Tablo 1'de Türk ve Alman hesap planlarının çeşitli açılardan bir karşılaştırması yer almaktadır. Karşılaştırmada Türkiye için 01.01.1994 tarihinde kullanımına başlanan Tek Düzen Hesap Planı ve Almanya için ise Endüstri İşletmeleri Hesap Planı esas alınmıştır.

\footnotetext{
3 Türkiye Cumhuriyeti Devlet Demiryolları tarihçesi kurumun açık bilgi niteliğindeki internet sayfasından derlenmiştir. http://www.tcdd.gov.tr/home/detail/?id=267, (Erişim Tarihi: 29.01.2014)
} 
Tablo 1: Türk ve Alman Hesap Planlarının Karşılaştırılması

\begin{tabular}{l|c|c|}
\hline \multicolumn{1}{c|}{ Karşılaştırma Kriterleri } & $\begin{array}{c}\text { Türk Tek Düzen Hesap } \\
\text { Planı }\end{array}$ & Alman Hesap Çerçevesi \\
\hline 1. Dış Yapı Bakımından & $\begin{array}{c}\text { Ondalık Rakamlarla } \\
\text { Simgeleme }\end{array}$ & $\begin{array}{c}\text { Ondalık Rakamlarla } \\
\text { Simgeleme }\end{array}$ \\
\hline 2. İçyapı Bakımından & & Uygun \\
\hline $\begin{array}{l}\text { 2.1. Hesaplara Düşülen İşlem Yoğunluğu } \\
\text { Ilkesi }\end{array}$ & Uygun & Uygun Değil \\
\hline 2.2. Bilanço Bölümleme İlkesi & Uygun Değil & Çift Taraflı Kayıt Sistemi \\
\hline 3. Muhasebe Yöntemi Açısından & Çift Taraflı Kayıt Sistemi Birci \\
\hline 4. Muhasebe Sistemi Açısından & Ölçülü İkici & \\
\hline
\end{tabular}

Tablo 1'den görüleceği üzere teorik ve sistematik anlamda Türk ve Alman hesap planlarının birbirine yakın oldukları rahatıkla söylenebilir. Temel fark "Muhasebe Sistemi Açısından” Alman Hesap Çerçevesinin maliyet hesaplarına daha fazla yer vermesidir. Bunun da temel nedeni olarak Alman hesap çerçevesinin endüstri işletmelerine göre düzenlenmiş olmasından kaynaklandığ 1 söylenebilir. Ayrıca bu sistemde işletme muhasebesi (maliyet muhasebesi) hesaplarına geniş yer verildiğinden, işlem muhasebesi (finansal muhasebe) hesaplarına daha az yer verilmiştir. Türkiye'de kullanılan Tek Düzen Hesap Planı ise işlem muhasebesi hesaplarına (finansal muhasebe) daha çok, işletme muhasebesi hesaplarına (maliyet muhasebesi) daha az yer veren bir yapıdadır. Bu da sistem olarak Türk Tek Düzen Hesap Planı'nın "ölçülü ikici” sisteme daha yakın olması anlamına gelmektedir. Bunun dışında her iki yapının benzer olduğunu açıkça görebilmekteyiz.

\section{TCDD BILANÇOLARINDA ALMAN MUHASEBE SISTEMININ ETKİSI}

Konu çerçevesinde Türkiye Cumhuriyeti Devlet Demiryollarının 1953 ve 1955 yılları ile 1970, 1971, 1972 ve 1973 yılları bilanço örneklerine yer verilmiştir. Bu yıllar Türk muhasebe hayatındaki Alman etkisinin görülebilmesine yönelik olarak seçilmiş özellikli yıllardır. 


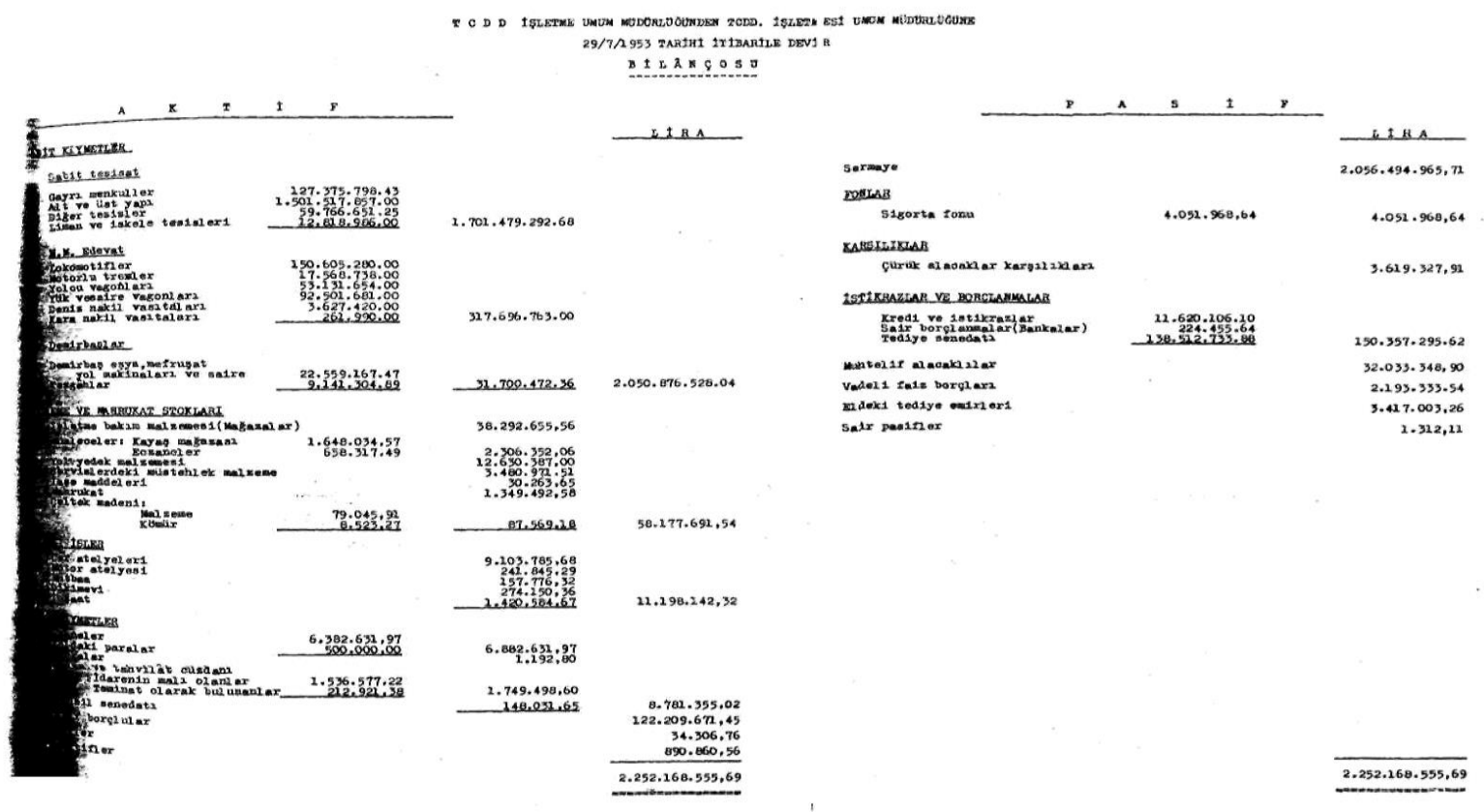

Resim 1: TCDD’nin 29.07.1953 tarihli Altı aylık Bilanço Görüntüsü

Kaynak: Türkiye Cumhuriyeti Devlet Demiryolları tarihçesi kurumun açık bilgi niteliğindeki internet sayfasından derlenmiştir. http://www.tcdd.gov.tr/home/detail/?id=267 (Erişim Tarihi: 29.01.2014).

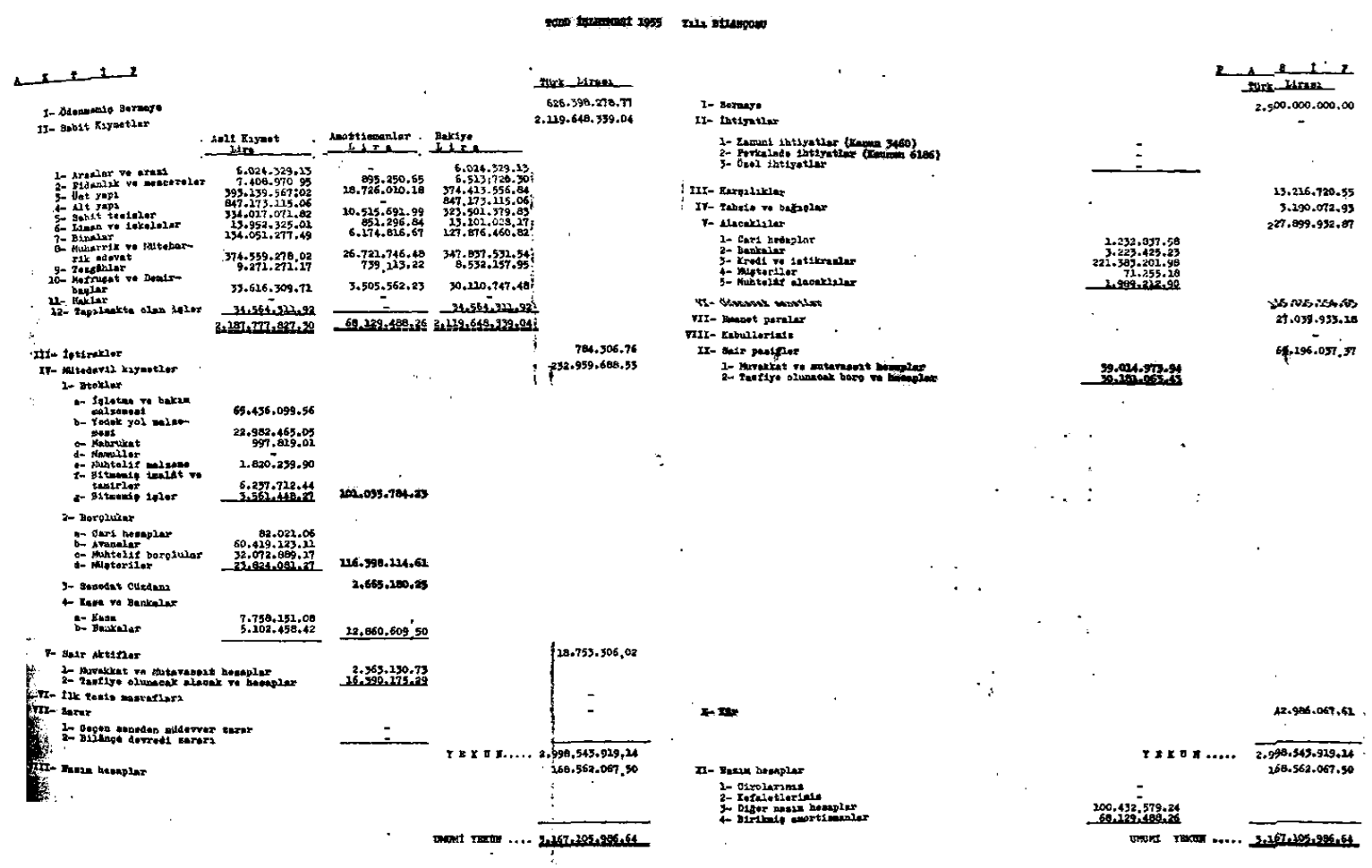

Resim 2: TCDD’nin 31.12.1955 tarihli Altı aylık Bilanço Görüntüsü

Kaynak: Türkiye Cumhuriyeti Devlet Demiryolları tarihçesi kurumun açık bilgi niteliğindeki internet sayfasından derlenmiştir. http://www.tcdd.gov.tr/home/detail/?id=267 (Erişim Tarihi: 29.01.2014). 
Optimum Journal of Economics and Management Sciences, Vo1. 7, No. 1- http://dergipark.gov.trloptimum Demirel and Tarakcıŏglu Altınay - Status of German Accounting System in Turkish Accounting Life: The Case of Republic of Turkey State Railways

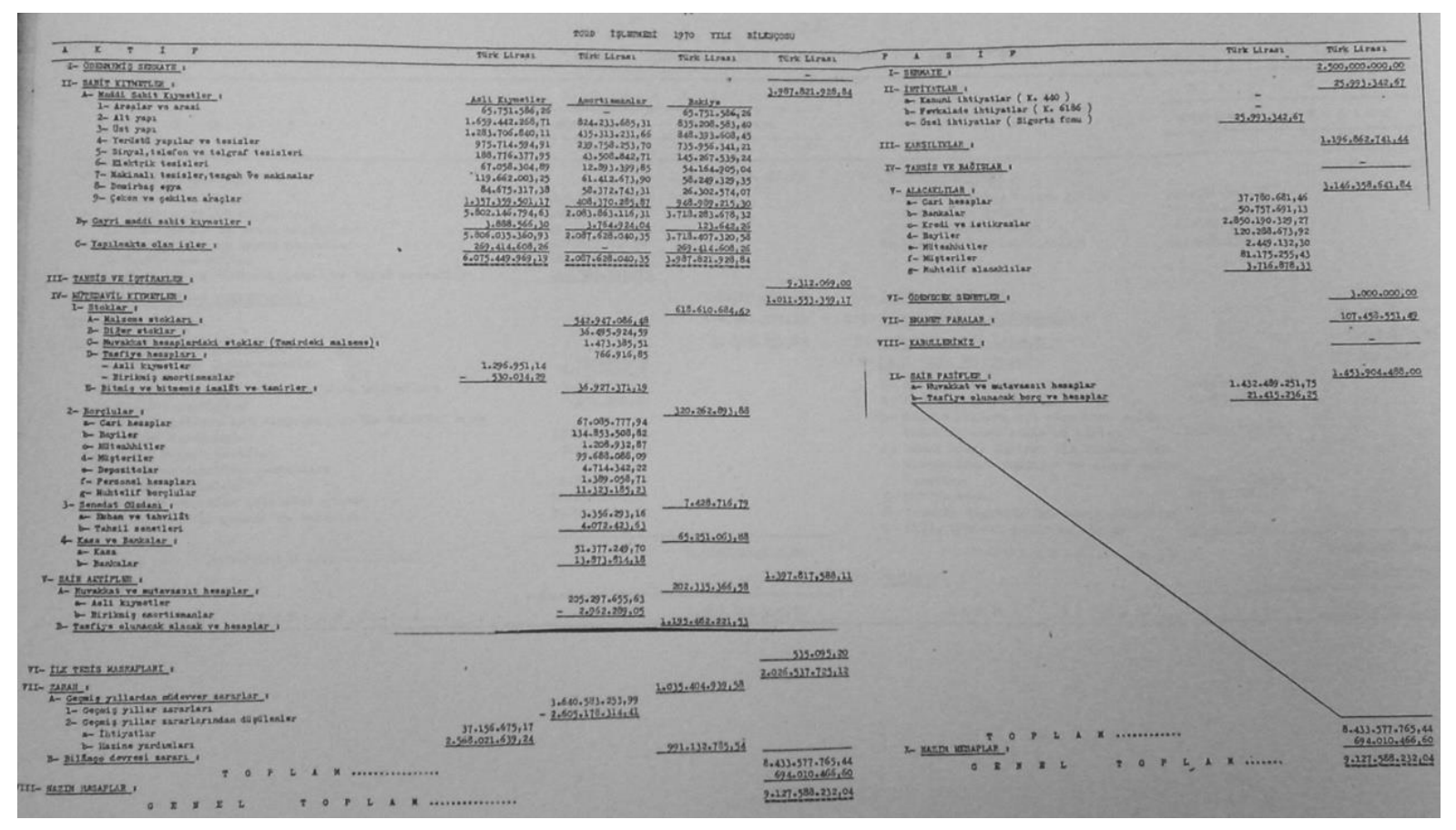

Resim 3: TCDD’nin 31.12.1970 tarihli Dönem Sonu Bilanço Görüntüsü

Kaynak: Türkiye Cumhuriyeti Devlet Demiryolları tarihçesi kurumun açık bilgi niteliğindeki internet sayfasından derlenmiştir. http://www.tcdd.gov.tr/home/detail/?id=267 (Erişim Tarihi: 29.01.2014).

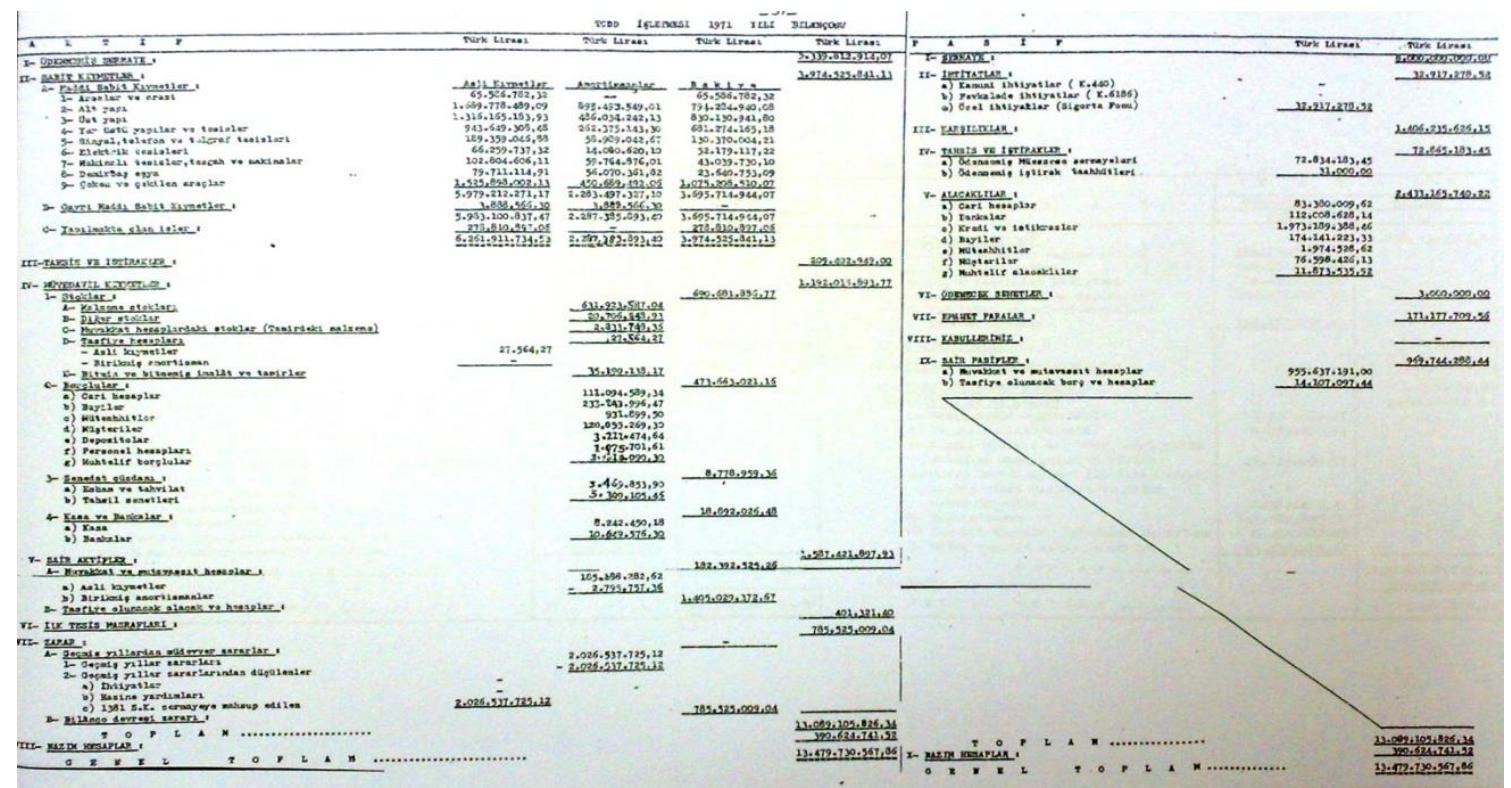

Resim 4: TCDD’nin 31.12.1971 tarihli Dönem Sonu Bilanço Görüntüsü

Kaynak: Türkiye Cumhuriyeti Devlet Demiryolları tarihçesi kurumun açık bilgi niteliğindeki internet sayfasından derlenmiştir. http://www.tcdd.gov.tr/home/detail/?id=267 (Erişim Tarihi: 29.01.2014). 


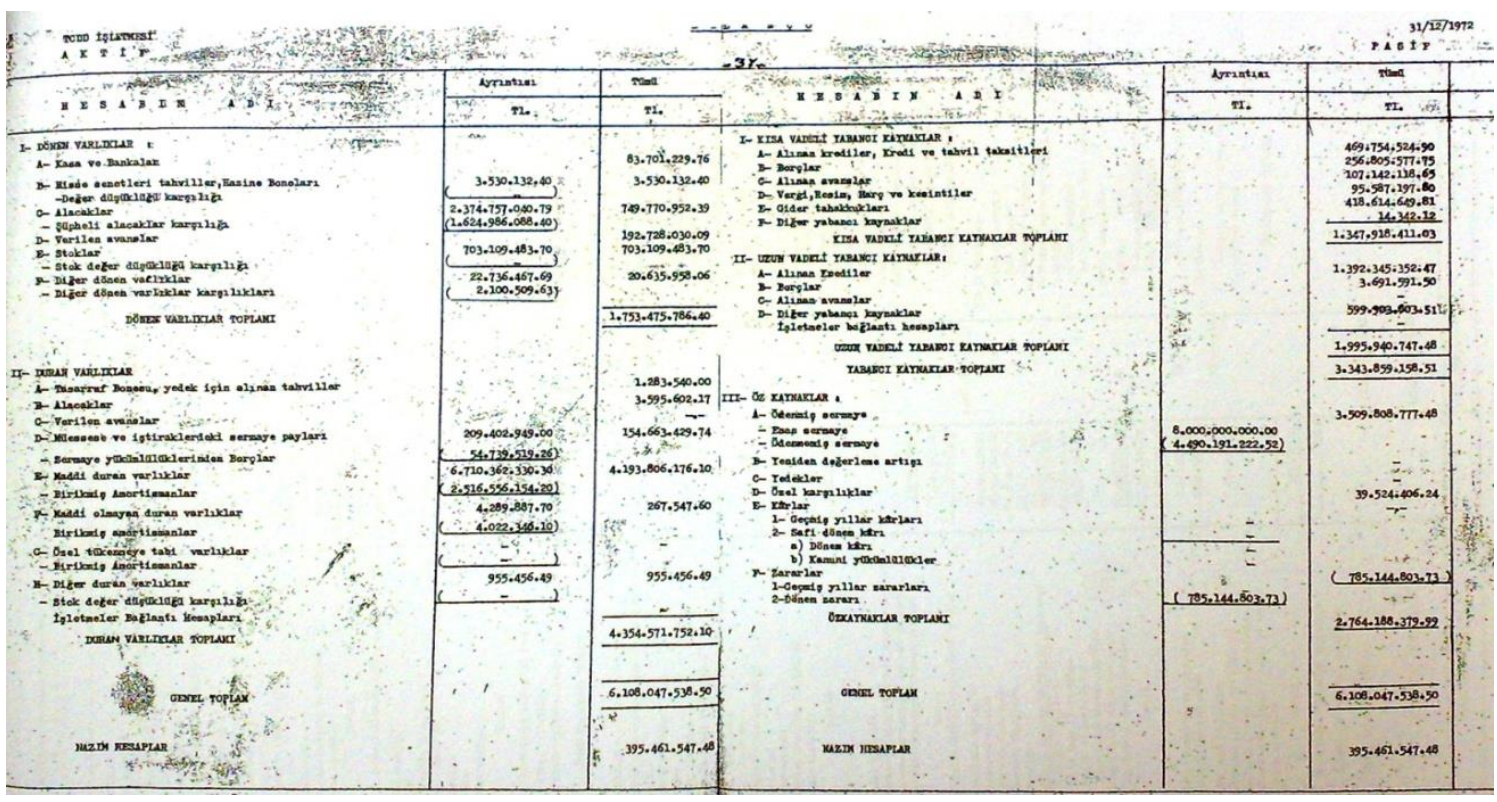

Resim 5: TCDD’nin 31.12.1972 tarihli Dönem Sonu Bilanço Görüntüsü

Kaynak: Türkiye Cumhuriyeti Devlet Demiryolları tarihçesi kurumun açık bilgi niteliğindeki internet sayfasından derlenmiştir. http://www.tcdd.gov.tr/home/detail/?id=267 (Erişim Tarihi: 29.01.2014).

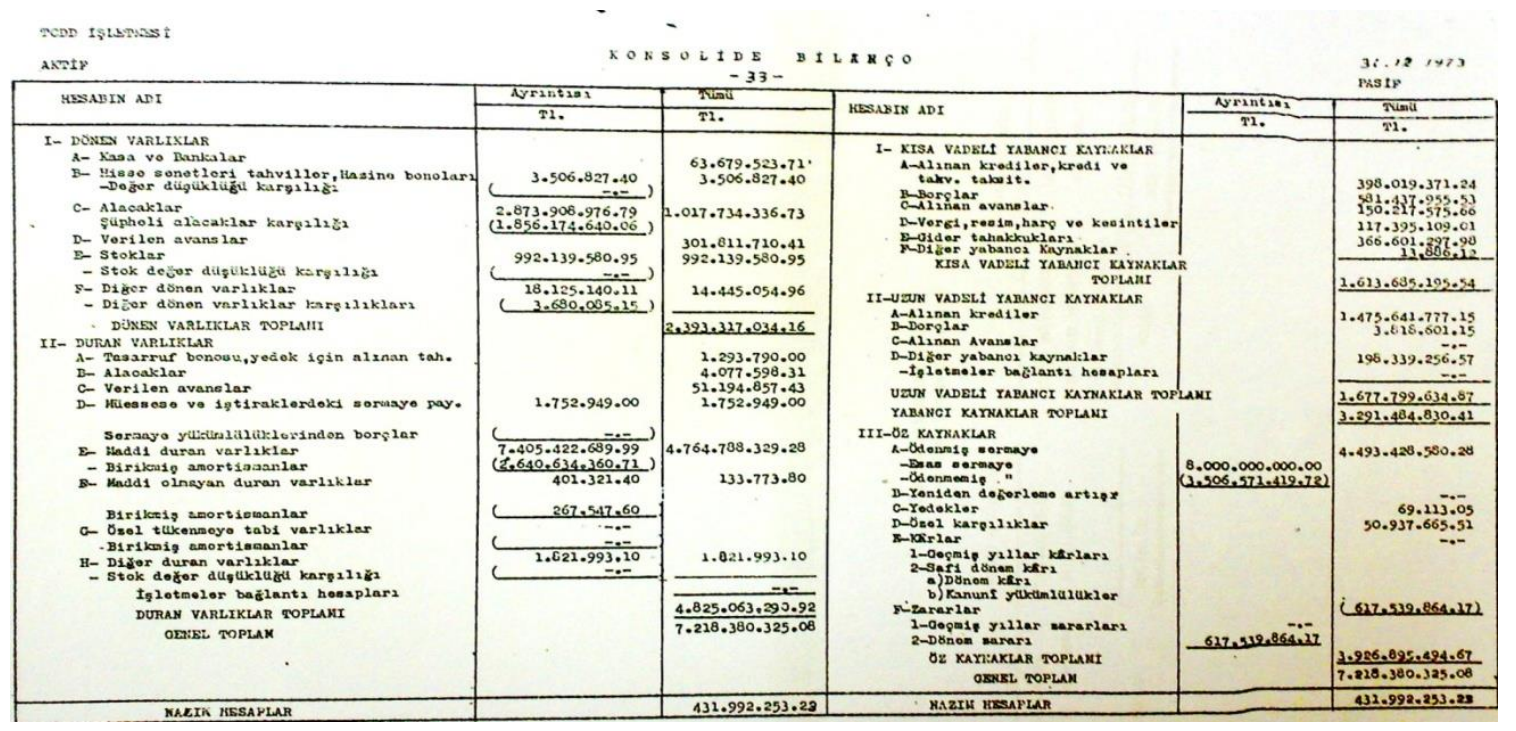

Resim 6: TCDD’nin 31.12.1973 tarihli Dönem Sonu Bilanço Görüntüsü

Kaynak: Türkiye Cumhuriyeti Devlet Demiryolları tarihçesi kurumun açık bilgi niteliğindeki internet sayfasından derlenmiştir. http://www.tcdd.gov.tr/home/detail/?id=267 (Erişim Tarihi: 29.01.2014). 
Çalışmada yer alan bilançolar incelendiğinde genel bilanço yapısının;

\title{
AKTIF TARAF
}

\author{
Duran Varliklar \\ Dönen Varlıklar
}

\section{PASIF TARAF}

Özkaynaklar

Karşıllklar

Borçlar (Yükümlülükler)

şeklinde sıralandığı; söz konusu sıralamanın 1972 yılı dönemsonu bilançosu ile değiştiği ve Türkiye'nin hâlâ kullanmakta olduğu "likidite esasına" dayalı hale dönüştüğü açık bir şekilde görülmektedir.

Söz konusu Alman etkisinin 1953 yılından daha önce de olduğunu görmek mümkündür. Ancak bu yıllara ait TCDD işletmesine ait bilançolara ulaşılamamıştır. Bu nedenle örnek tespit edilebilen ilk yılın ve müteakip yılların örnekleri verilmiştir.

\section{SONUÇ ve GENEL DEĞERLENDIRME}

Çalışmanın amacı doğrultusunda konuyu ele aldığımızı ve önemli bir örnek ile kanıt bulduğumuzu söyleyebiliriz. Özellikle Türk Tek Düzen Hesap Planı ile Alman Hesap Çerçevesi'nin Dış Yapı, İç Yapı ve Muhasebe Yöntemi açısından aynı olmaları ve tek farklılığın sadece Muhasebe Sistemi açısından oluşu da bu iki muhasebe anlayışının birbirine önemli ölçüde benzediğinin bir göstergesidir.

Geçmişte özellikle 1950’lerde başlayıp 1972 yılına kadar devam eden bir Alman muhasebe etkisinden artık daha kolay ve ikna edici bir şekilde bahsetmek mümkündür. Özellikle 1970'ler Türkiye'de muhasebe alanında önemli kırılmaların yaşandığı bir dönem olmasından dolayı bazı işletmelerde Alman bilanço mantığının 1971 yılından birkaç yıl önce veya birkaç yıll sonra terk edildiğini söylemek mümkündür. Bu bağlamda Alman bilanço anlayışının terk edildiği tarih için kesin bir tarih verilememekle birlikte, Alman bilanço mantığının 1968 yılında İktisadi Devlet Teşekküllerini Yeniden Düzenleme Komisyonu (IDTYDK)'nun hesap planı çalışmaları ile birlikte terk edilmeye başlandığını söylemek mümkündür.

\section{KAYNAKÇA}

Akdoğan, N. \& Aydın, H. (1987). Muhasebe teorileri, Ankara: Gazi Üniversitesi Yayın No: 98.

Alman Ticaret Kanunu (Deutsche Handelsgesetzbuch). Yayınlanma Tarihi: 10.05.1897. Güncellenme Tarihi: 20/12/2012.

Arıkan, Y. (1996). Uluslararası muhasebe standartları Türkiye uygulaması. Mali Çözüm, 6(36).

Aysan, M. A. (1996). Muhasebenin tarihsel ve çağdaş konumlarından geleceğe bakış, Ankara: TÜRMOB Yayınları No:23.

Aysan, M. A. (2009). Uluslararası muhasebe standartlarına ulusal uyum: Türkiye örneği, Muhasebe ve Finansman Dergisi, 42, 42-53.

Bayazıtlı, E. (2000). Gelecek Yüzyılda Muhasebe Eğitimi, Ankara: TÜRMOB Yayınları No: 139.

Bilginoğlu, F. (1988). Muhasebe Organizasyonu, İstanbul Üniversitesi, İşletme Fakültesi, İstanbul: Muhasebe Enstitüsü Yayın No:54.

Çürük, T. (2001). Muhasebe eğitiminin işletmelerin taleplerini karşılama düzeyi: Türkiye örneği. ODTÜ Gelişim Dergisi, 28, 3-4. 
Elitaş C., Güvemli O., Aydemir O., Erkan M., Oğuz M. \& Özcan U. (2008). Accounting method used by ottomans for 500 years: Stairs method, Ankara: Maliye Bakanlığı Yayınları.

Elitaş, C. (2014). Muhasebenin kuramsal temelleri. Yalova: Yayımlanmamış Ders Notları.

Güneş, R., Durmuş, A. F. \& Solak, B. (2012). Küreselleşmenin muhasebe uygulamalarına etkisi, Akademik Yaklaşımlar Dergisi, 3(2).

Güvemli, O. (2006). World Congresses Relevant to Accounting and Congresses and Symposiums, Istanbul, 2006'dan aktaran Aysan, M. A. Uluslararası muhasebe standartlarına ulusal uyum: Türkiye örneği, Muhasebe ve Finansman Dergisi, 42.

Koç, Y. (1972). Tekdüzen muhasebe sistemi, Ankara Üniversitesi Siyasal Bilgiler Fakültesi Dergisi, 27(3).

Kroll, H. (2000). Rechnungwesen im Handwerk, 3. Bask1, Hannover: Schlütersche.

Örten, Remzi, (1988). İşletme ve Muhasebe Bülteni, 25.

Selimoğlu, S. K., Aslan, Ü. \& Güvemli, B.(2009). Bir literatür incelemesi, Muhasebe ve Finansman Dergisi, V:42.

Sevilengül, O. (2000). Genel muhasebe, 9. Basım. Ankara: Gazi Kitabevi.

Sutter, R. (2007). Geschichte der doppelte buchhaltung, Bern, 2007.

Toraman, C. Bayramoğlu, F. (2006). Effects of the adoption of european union standards on accounting practices, Journal Of Financial Analyze, Special Issue Published by Istanbul Chamber Of Certified Public Accountants for 17th World Congress Of Accountants, 13-16 November.

Toraman, C., Bayramoğlu, M. F. (2006). Effects of the adoption of European Union standards on accounting practices, Muhasebe ve Finansman Dergisi. 220-241.

Ünal, O. \& Doğanay, M. (2009). Lisans düzeyindeki muhasebe eğitiminin etkinliği: Sayıştay özelinde ampirik bir çalışma, Sayıştay Dergisi, 74-75.

Yazıcı, M. (1998). Muhasebe tümlemleri ve örgütlenmesi, 2.Baskı, İstanbul: Nihad Sayâr Eğitim Vakfı Yayın No: $522 / 756$.

Zimmermann J., Werner J. R., Volmer P. B. (2008). Global governance in accounting, Rebalancing Public Power and Private Commitment, Transformations of the State Series, Palgrave Macmillan. 


\section{Extended Summary}

\section{Status of the German Accounting System in Turkish Accounting Life: The Case of The Republic of Turkey State Railways}

The aim of the study is to reveal the German Accounting System which was implemented in Public Enterprises of the Republic of Turkey between the 1953-1954 and 19711972 years. For this reason, the financial statements of the Turkish State Railways between 1953-1973 years are analyzed in this study. In this period, content analysis is made by comparing the general account plan used in Germany and the account plan of the enterprise in various aspects and structurally.

The aim of this study is to follow "the traces of the change in "accounting life" starting with the implementation of the double-sided recording technique in the Ottoman Empire the Republic of Turkey. For this purpose, the effects of the "German Accounting " approach that we think started as 1950-1951 and continued until 1970-1971 are examined and investigated instead of the effect of French Accounting that began in the establishment of the Republic of Turkey (1923) until 1950-1951. At the same time, this study is evaluated the aspect of "'Government Agencies' Accounting'. In this research, the content analysis technique which is one of the research techniques in social sciences is used as a method.

For this purpose, after the first section where the Turkish accounting history process will be given as a summary, it continues with the second section where the German Accounting System will be introduced with the basic elements. In the third section continues that the financial statements of TCDD between 1953-1975 years are examined. In the fourth and last section of the study, general evaluations and intuitive convictions are included in the light of the findings and findings.

Related years in the Republic of Turkey Accounting of one of the businesses that used the Republic of Turkey State Railways (TCDD) financial statements (balance sheet - income statement) structure, "General German Financial Statements Buildings" will be compared from various angles. This comparison will be made on "account plans and the main evaluation headings;

- in terms of external structure [which is chosen by letters, numerals and hash symbols],

- in terms of internal structure [the questions of what is the situation in terms of transaction density principle, partitioning principle according to balance sheet, partitioning principle according to the actions taken in the enterprise and the principle of economic value circulation] will be sought;

- in terms of the accounting recording method [unilateral recording method, double recording method or mixed recording method preferred] and

- from the standpoint of the accounting system [which is the preferred system of monist, dualist, limited monist and limited dualist].

The significant accounting developments from 1850 until the present day in this region in the process extending from the Ottoman Empire to the Republic of Turkey will be discussed. These developments will be given in chronological order.

The subjects discussed in the study were obtained as a result of a comprehensive literature research using content analysis technique which is one of the research methods in social sciences. 
Turkey has been influenced by countries with intense economic and political relations in the development of Turkish accounting literature and legislation. In our accounting practices, firstly France and then Germany had significant effects.

The effect of German accounting literature was observed for a while due to the fact that The Commercial Code no. 856, which came into force in 1926 during the Republican period, was based on the German Commercial Code. For this reason, there are also determinations that the German influence began in these years and continued until the 1960s.

Legal norms of accounting rules in Turkey as the first French accounting rules, is then advanced German influence. This shows that it is included in the tradition of the Land Europe. As mentioned earlier, the Turkish Commercial Code dated 1957 and the Tax Procedure Law dated 1961 have shaped accounting practices for a long time. It should not be forgotten that these regulations were created under German influence. For this reason, accounting, which is shaped by laws, has brought with it the predisposition to the German school which is the source of the laws.

Since the Turkish Commercial Code No. 865, which entered into force in 1926, was taken through translation from the German Commercial Code, it can be said that the German influence in accounting literature started after this date.

It is possible to see that in the Turkish Accounting literature during the last periods of the Ottoman Empire and the Republican and post-Republican periods, accountants and accounting courses were influenced by the French and German schools. German and French accounting practices directly affected a small number of Turkish accounting trainers and a few number of private sector accounting practices and accounting practices in the Public Economic Enterprises (PEE). Accounting practices and training in Turkey began before the Republic and it proceed by the French School in 1926 and later. In this period, the departments where accounting education was given in universities were established and accounting education was expanded. It is generally accepted in the literature that the effect of American and British (Anglo-Saxon) increased in Turkish accounting education after the 1960. However, it is possible to say that the German balance sheet structure could be seen until 1972, especially in the Public Economic Enterprises.

In the development of Turkish accounting literature and legislation are influenced by countries that we are in relation as intense economic and political. Firstly France and then Germany had significant effects in our accounting practices.

The effect of German accounting literature was observed for a while due to the fact that The Commercial Code no. 856, which came into force in 1926 during the Republican period, was based on the German Commercial Code. For this reason, there is also evidence that the German influence began in these years and continued until the 1960s.

Because of a period of major breaks in the accounting field in Turkey especially the 1970 s, it is possible to say that the logic of the German balance sheet was abandoned by some enterprises a few years before 1971 or a few years after 1971. In this context, although it is not possible to give a certain date for the abandonment of the German balance sheet approach, it is possible to say that the logic of the German balance sheet began to be abandoned in 1968 with the work of the accounts chart by the Committee on the Readjustment of Public Economic Enterprises. 
Optimum Journal of Economics and Management Sciences, Vo1. 7, No. 1- http://dergipark.gov.tr/optimum Demirel and Tarakcıŏglu Altınay - Status of German Accounting System in Turkish Accounting Life: The Case of Republic of Turkey State Railways 